\title{
Politics-Administration Interface and the Sustenance of Public Service Ethos in South-West Nigeria
}

\author{
AFEGBUA, Salami Issa
}

\section{Abstract}

His work examined politics-
administration interface and the sustenance of public service ethos in Southwest Nigeria. Public servants and political functionaries in Southwest Nigeria are constantly in a struggle to fix each other in their pre-conceived mould of mental judgment which invariably breeds mutual suspicion, apprehension and setting the stage for conflict which is likely to impact negatively on the performance of public servants in Southwest Nigeria. The article identified the factors influencing the interface of public servants and political office holders in Southwest Nigeria. It also determined the influence of the interface between on public service ethos and finally examined the efforts made towards sustaining public service ethos in Southwest Nigeria. In carrying out this work, primary and secondary data were used. In the case of primary data, survey was carried out and questionnaire was used to elicit information from respondents in the Southwest geo-political zone of the country. Purposive random sampling techniques were adopted to determine the target respondents. The study has a sample of five hundred and thirty-five (535), which constitute 50 percent of the total population figure of 1070. The findings revealed amongst others, that the synergy between political functionaries and public office holders is often characterized by both conflict and cooperation. In addition, there are certain factors influencing the interface of public servants and political office holders in Southwest Nigeria, these factors include: contract awards, consideration in the appointment of top civil servants etc. The study therefore, recommends the need for Southwest Nigeria to strengthen politicsadministration interface in such a way that the public services in that region will be more productive. There is also the need for government in the Southwest to clarify the respective roles of political office 
holders and public servants. The principles and ethos governing the roles and responsibilities of political office holders and public servants should be clearly spelt out. The study concludes that despite the commendable efforts made by public service in Southwest Nigeria, lack of strict adherence to ethical values has made it difficult for such interface to enhance compliance with standard ethical practices. The article therefore recommends, amongst others, the need to strengthen politics-administration relations in Southwest Nigeria. Moreover, government in the Southwest geo-political zone of Nigeria should organize retreats on a regular basis for both political functionaries' and public officials on the need to uphold the ethics and principles of the service as well as adhere to their respective codes of conduct for public officers.

Keywords: Politics, bureaucrats, Ethics, Politics-Administrations Relations, Southwest Geo-Political Zone.

\section{Introduction}

Politics-administration relations from the time of John Locke till today have been the subject of intense debate among scholars (Fatile, 2013: 46). At the turn of the 19th century there was hardly any basic textbook in public administration that did not devote some space to the subject matter of politics-administration (Dasandi, 2014: 112). The politics-administration interface originated from dichotomy doctrine. Prior to the 1920s, the traditional assumption that there was a clear distinction between politics and administration held sway. It was assumed that politics was essentially concerned with the processes connected with the shaping and uses of state power, while administration was the means by which the realization of policy objectives were attained. It was argued that administration must divorce itself from the field of politics (Fatile, 2013: 47).

The argument for the separation of politics from administration received the endorsement of a considerable number of scholars such as Wilson, 1887; Goodnow, 1900; Willoughy, 1918; Pfiffner, 1935; and White, 1948. Wilson in his essay, The Study of Administration, published in 1887 illuminated and publicised the classical discourse of politics-administration dichotomy (Laximikanth, 2011). The politics-administration 
dichotomy came to limelight during the time when the American public administration was dominated by spoils politics and patronage system. It is against that backdrop that Wilson (1887) stressed that administration should be treated separately from politics because; "Administration lies outside the proper sphere of Politics and that administrative question is not political question" (Fatile, 2007:98).

Prior to independence in 1960, the public service in the Southwest geo-political zone of Nigeria was regarded as one of the best in the Commonwealth, and up till the mid1980s (Gboyega, 1995: 30). Lagos state public service that emerged from the western region public service was regarded as one of the most efficient in Nigeria (Olowu, 1999: 96). In the past, the public service at both the federal and regional levels recruited public servants on merit and was characterised by the ethos of anonymity, impartiality, neutrality, and security of tenure. Public service was geared towards efficiency standards, and was largely untouched by crude politics (Adegoke, 2013: 9). Public service used to be strong and formidable; and the relationship between political office holders and career public servants were built on respectable ethos such as honesty, impartiality, political neutrality, hard work, commitment, etc. that was not easily compromised by any of the parties (Salami, 2010). Public service ethos was sacrosanct and highly respected by political office holders. The service was perceived as a strong institution guided by certain values, high ethical standards and culture which differentiated it from other types of public institutions in the country. It was an enviable institution that endeared all and sundry to join. The public service became the cynosure of all eyes. Employees started and ended their career in the public service without fear of being sacked (Omoyele, 2012). The model of Public Service bequeathed to Nigeria by her colonial master (Britain) was narrow in structure and objectives; it was basically structured in such a manner that enabled colonial masters to successfully extract the much coveted financial and material resources needed by their controlling metropolitan powers, therefore, colonialism was marked by a lack of accountability and absence of transparency (Wiarda, 2002)

Public service ethos in Southwest Nigeria gradually became eroded immediately after independence when career office holders began to violate the tradition of anonymity and political neutrality of the public service and thus, dented the image of the public service. Against all odds, career office holders played positive roles during the Nigerian civil war, as delegates to some parts of Africa in quest of peace and intensified effort in development of economic and social programmes, taking advantage of the weak 
political control and political consensus. It should be noted that the military incursions of 1966, 1975 and 1984 contributed to the lapses and moral decay of the career public servants, which derailed career office holders off the norm of being apolitical and anonymous. This situation degenerated into breakdown of public accountability and lack of probity. Consequently, embezzlement and corruption became the order of the day, thereby resulting in ineffectiveness and low productivity in the service (Iheme, 2003).

Political neutrality provides stability in the service. Once a public servant is a party member, he becomes partisan and this contravenes his or her professional calling. Moreover, where public servants belong to political parties, an acute instability of tenure will arise. In some cases, the political party in power will create regime of favouritism or some other disguised sanctions by which public servants will be compelled to belong to the ruling party. The weakening of the existing traditions of anonymity, political neutrality and impartiality has led to the creation of a 'political' public service (Abiona \& Oladoyin, 2008:1).

\section{Statement of the Problem}

Globally, public service ethos is usually sustained to protect and preserve the sanctity of the public service. The problem, which most developing countries, including Nigeria has to contend with for so long, is how to handle the crises that emanate from the interface between public servants and political office holders. In recent times, relationship between public servants and political office holders in the public service of Southwest Nigeria has been strained. This has resulted in suspicion whereby parties see themselves as competitors rather than partners in progress. Political office holders in Southwest geopolitical zone of Nigeria perceive public servants as lethargic, incompetent, uncooperative and corrupt. Public servants, on the other hand, see political functionaries as parochial, greedy, self-seeking, self-centred, inexperienced, immature and highly wasteful.

Public services in Southwest Nigeria have continued to witness recurring, persistent and ugly incidence of political-administrative relations arising from such interface. The crisis emanating from the interface in Southwest Nigeria is discernible in public servants performing duties of political executives and generally conducting themselves as political functionaries as against the laid down ethos. Moreover, the crisis of interface has led to the jumping of official channels of communication often to subvert superiors before the 
political leadership, thereby creating feelings of alienation that may breeds discontent. Public servants in the Southwest geo-political zone sometimes publicly enunciates or comment on decided government policies; even openly canvassing partisan political views and registering as card carrying members of political parties in their states. All the above actions and more are in direct contravention of the existing regulations, accepted norms and ethics of the public service (Oladoyin, 2012: 126). There is a dearth of research that directly addresses the politics-administration relations in the public services of any of the geo-political zones of Nigeria. Past studies such as: Adeyemo \& Osunyikanmi, 2009; Oladoyin, 2011; Nwasike, 2013; Ndulala, 2013 etc. did not focus on Southwest Nigeria and failed to provide insight into possible alternatives for addressing the challenges of politics-administration relations. Most of the studies also fail to provide adequate information on politics-administration relations in their various areas of study; hence this study seeks to fill the above gaps. The study provides a clear understanding of politics-administration interface in relation to the sustenance of public service ethos in Southwest Nigeria. The study also helps to discover adequate model of politicsadministration relations in the study area.

\section{Objectives of the Study}

1) Examine the various cases of politics-administration interface in Southwest Nigeria;

2) identify the factors influencing the interface of public servants and political office holders in Southwest Nigeria;

3) determine the influence of the interface on public service ethos in the selected states in Southwest Nigeria; and

4) examine efforts made towards sustaining public service ethos in the study area

\section{Research Questions}

1) What are the various cases of politics-administration interface in Southwest Nigeria?

2) What are the factors influencing the interface of public servants and political office holders in the selected states of the region?

3) How can one determine the influence of the politics-administration interface on public service ethos in the selected states in Southwest Nigeria? 
4) What are the efforts made towards sustaining public service ethos in the study area?

\section{Methodology}

Southwest Nigeria is made up of Lagos, Osun, Oyo, Ogun, Oyo and Ekiti states. This work covers three purposively selected states of Lagos, Osun and Ondo. It adopts a survey research design. The study has a sample of five hundred and thirty-five (535) respondents, which constitutes 50 percent of the total population figure of 1070 . Purposive random sampling techniques were adopted to determine the target respondents. The study used primary and secondary methods of data collection. Quantitative data were collected through personally administered questionnaire on various categories of public servants and political office holders. While qualitative data were extracted through the conduct of in-depth personal interview. In order to complement the data from primary sources, some information were collected through secondary data. Descriptive statistics, most especially simple percentage was also adopted in the study. The secondary materials were sourced from academic literature on the subject matter, the various publications of the selected ministries, internet materials, textbooks and relevant classified government publications.

\section{Conceptual and Theoretical Discourse}

\section{Politics}

The word 'Politics' is usually used without providing an explicit definition. There have been wide range definitions of politics; Thornhill (2012: 65), identified politics with government, or the state, while Almond (2007:167) says politics revolves around the notions of power, influence, authority and/ or conduct. To the average citizens, politics and government are synonymous. It seemed natural to identify politics with what occurred at the national assembly or the council chairman's office. Many average citizens viewed politics as happenings at the three tiers of government: Legislature, Executive and Judiciary (Okotoni \& Eroro, 2005). The notion of politics is derived from the Greek word 'polis' meaning a 'city state' such as Athens or Sparta. Appleby (1984) identified Politics is identified as everything having to do with the government and everything the government does (Appleby, 1984: 43). Politics is also described as 'Who Gets What, 
When, How'? (Lasswell, 1934). From this perspective, politics is about diversity and conflict, but the essential ingredients are the existence of scarcity: the simple fact that, while human needs and desires are infinite, the resources available to satisfy them are always limited. Politics can therefore, be seen as a struggle over resources and power (Demir, 2008).

There are four ways by which politics can be conceptualized. According to Aremu (2003), politics is seen as the art of Government. This definition of politics is state or institution-centred because it views politics as what 'government' or 'states' do. This means that most people, most social activities can be regarded as being 'outside' politics. Businesses, schools and other educational institutions, community groups, families and so on are in this sense 'non-political (Almond, 2007). A second and broader conception of politics moves it beyond the narrow realm of government to what is thought of as 'public life' or 'public affairs.' In other words, the distinction between the 'political and 'the non-political' coincided with the division between an essentially public sphere of life and what can be thought as a private sphere (Almond, 2006).

The third conception of politics relates to the way in which decisions are made. Specifically, politics is seen as a particular means of resolving conflicts: that is, by compromise, conciliation and negotiation rather than through naked power. Politics became the process of conflict resolution. In this view, the key to politics is a wide dispersal of power. Accepting that conflict is inevitable and social groups possessed and competed for power, they must be conciliated; and they cannot be merely crushed (Oladoyin, 2008). The fourth definition of politics is both the broadest and most radical. Rather than confining politics to a particular sphere (the government; the state or the 'public' realm), this view sees politics at work in all social activities and in every corner of human existence. In this sense, politics takes place at every level of social interaction; it can be found within families and amongst small groups of friends, just as much as amongst nations and on the global state (Rohr, 2003). At its broadest sense, politics is concerned with the production, distribution and the use of resources in the course of social existence. Politics is, in essence, power - the ability to achieve a desired outcome, through whatever means (Demir, 2003).

Politics is viewed as the process through which power and influence can be obtained and exercised. It also includes decisions concerning the goals to be achieved, the utilization of resources and the means of bringing about equilibrium in the various 
spheres of social life (Carboni, 2010). Wilson identified two types of politics: partnership and patronage politics. He was of the opinion that patronage politics should be removed from administration. He maintained that administrators are politicians to some extent and that politics gives room for patronage. Against this backdrop, he advocated for politics-administration dichotomy. He further recommended partnership politics that brings about political neutrality on the part of administrators. Goodnow (1900), saw politics as 'the expression of the will of the state' and administration as 'the execution of that will' (Nchuchuwe, 2007). Politics is also viewed as an activity that involves the exercise of power, but more importantly, as an activity that serves a purpose.

\section{Political-administration interface}

Political-administration interface according Nwasike (2013) is a term used to describe the functional relationship between the politicians (ministers) and administrators (permanent secretaries). Hanekon, Rowland \& Bain (2013), defined political-administration interface as a special field of activities that is underpinned by indefinable basis which can serve as guidelines, values and norms in which roles and responsibilities of those in public offices have to employ and adhere to. Hence, the political-administration interface operated mainly in public institutions where public administration regulated its function. Politicaladministration interface is the relationship between politicians and public servants which lies in the heart of public administration. The relationship involved professional administration ethics and norms, which made a difference for public service delivery and performance of public affairs (Daly, 2012).

\section{Public Service Ethos}

Ethos comprises ideals as well as dispositions. Ethos is defined as a principled framework for action, something that described the general character of an organisation. Public service ethos essentially, is norm and value attached to what is right or wrong, appropriate or inappropriate within public institutions (Kwaghga, 2014). It is also a benchmark against which public servants and institutions should continuously strive to measure themselves. Public service ethos is the disposition, character or fundamental values peculiar to public servants. Public service ethos is an organisational culture that has traditionally been referred to as differentiating government organizations and their employees from other types (Needham, 2007). It sets the context for public sector 
employment. The study brought the public service ethos into the spotlight so that an assessment can be made on how administration is withstanding the pressures from the politics sphere. Public service ethos is an ideology applied to the character of public administration (Agba, Ochimana \& Abubakar, 2013). Public service ethos provides 'espirit de corps,' a feeling of sense of belonging among public service employees: a sense of unity, continuity and collegiality, when someone described himself or herself as 'Public Servant' it is testimony to the power of ethos (Akinola, 2012).

Makinde (2003) affirmed that the public service ethos is one of the shapers of integrity and values are associated with it. The supreme value is the public interest because the public administrator must consider not only those pressed before him but also the interest of those not adequately represented in the political process, in this way safeguarding social equity. Public service ethos has been expressed, in particular, by the characteristics of public servants, ideally altruistic community oriented, impartial, professional, and loyalty to the public. Public service ethos has ethical, cultural, historical and philosophical foundations with significant value attributed to it as a motivator to serve the public interest (Olaleye, 2005). The public service which served the country in the post-independence era inherited the ethos and traditions of the colonial public service which were patterned on the British Public Service. The public service ethos and traditions among others are Integrity, Impartiality or neutrality, Loyalty, Continuity, Adaptability and Anonymity. They are embedded in the Nigerian Public Service of today but they have not been effectively sustained (Olaopa, 2008).

This paper is situated within the context of bureaucratic politics theory which is considered relevant for the analysis in this paper. The Theory typically rejects the politics-administration dichotomy. Since bureaucracies and bureaucrats routinely engage in political behaviour, the theory places emphasis on the interface between political functionaries and bureaucrats. It justified the political role of bureaucracy. Bureaucratic politics exposes the rickety foundations of the politics-administration dichotomy (Salami, 2010).

Accordingly, the theory of bureaucratic politics sought to breach the orthodox divide between administration and politics. The goal of bureaucratic politics is not to locate the dividing line between politics and administration because no such line exists, nor is it ascertained how bureaucrats can be accountable to their political masters and bureaucratic politics theory sought to answer some questions important to bureaucracy. 
The emphasis of the theory is to what extent administrative processes as opposed to democratic process do. The theory determined who controlled or influenced the exercise of bureaucratic power and the role of bureaucracy in representing and advancing the goals of a particular clientele groups or organized interest (Brans, 2005).

There are two key organizational dimensions to bureaucratic politics theory. The first dealt with behaviour and ethics of the bureaucrats. The second dealt with institutional structure and distribution of powers. The primary goal here is to understand bureaucracy's formal lines of authority. The theory states something other than the product of the 'politics' end of the politics-administration dichotomy must drive the behaviour of bureaucrats and bureaucracies. Scholars such as Long, Gaus, and Waldo argue that bureaucracy is a political institution and that any useful theoretical framework has to recognize and account for this simple fact. Whether there is interface or not, bureaucrats or public servants must always respond to their professional values, ethos, peer expectations and ideology (Auritzer, 2002).

The theory of bureaucratic politics is the 'political interaction between bureaucrats and actors in the executive arm of government. The theory maintained that there are multiple actors in most bureaucracies and that these actors have diverging and conflicting interests. These relations required cooperation in areas of disagreement because of the necessity for future interactions. It maintained that bureaucratic politics is referred to as bureaucratic consensus-seeking. At the opposite end of the spectrum we find bureaucratic confrontation characterized by many players vigorously pushing their parochial viewpoint in a relative open and ill-structured manner (Barnee \& Burchard, 2013). The major disadvantages of bureaucratic politics theory were the undue emphasis placed on the primacy of politics over administration. The theory did not foresee the emergence of the New Public Management which relegated political influence to the background.

\section{The Fundamental Ideals of the Public Service}

The Public Service Hand book (1997), emphatically describes the public service as a body or organ which enjoys continuity of existence; whose members are not limited to a short term of office. Similarly, the public servants command a pool of expertise for implementing of government policies. The public service is distinguishable from the military service and police service in that while the latter two are principally concerned 
with the safeguard of the country from external and internal dangers, the former is concerned with purely civil and non-technical affairs of the state. Oladoyin (2012) posits that there are four fundamental ideals principles for the public service worldwide, they are: the principle of equality, principle of continuity, legality and neutrality. Similarly, he explained the four main characters of the public service as: Expertise, Impartiality, Anonymity and Political Neutrality.

Anonymity: states that public servants should be seen and not be heard. Though they advise political office holders on issues relating to government they neither take the blame nor the glory of such policies. They are not expected to be seen defending such policies. Public servants are not to be seen craving for publicity.

Neutrality: The civil servant must be politically neutral; his job is to serve the government of the day with full dedication irrespective of what he feels about that particular government. He ought not to allow personal prejudices to over shadow his dedication in the line of his duty. He is not expected to advertise political inclination for political parties or get involved in partisan politics though he is expected to vote at election times. The essence of making the civil servant politically neutral is hinged on the fact that since he does not leave with a change in government, he is not expected to have a strong attachment to any particular government so as to enable him give his best to make government policies succeed irrespective of his personal feelings towards such policies or government.

Impartiality: Public servants are paid from tax payers' money which does not belong to anybody or group in particular. They are therefore expected to discharge their duties without fear or favour. Since the constitution emphasizes the equality of all citizens, they are supposed to be treated equally by the public servants. In rendering service to the public, the civil servant is expected to treat very body with a high degree of impartiality. Favouritism is against the principle of the public service and should not be encouraged in any guise whatsoever.

Permanence: The public service is often defined as a permanent body of officials that carry out government decisions, it is permanent and its existence is not tied to the life of any particular government. Olaopa (2008), compared the public service with the 
'Barracks' because governments come and go but the public service is the organ of government that remains.

\section{Political-Administration Interface and the Sustenance of Public Service Ethos in Southwest Nigeria}

The Southwest comprised Lagos, Osun, Oyo, Ondo, Ogun and Ekiti states. The public services of Southwest geo-political zone of Nigeria were established to imbibe the ethos, culture, principles and standards expected of public servants anywhere in the world (Omoyele,2012:31). Chief Awolowo built and bequeathed a public service that was described as having one of the best hands and minds in the country. The service imbibed the core values of integrity, honesty, impartiality, continuity, objectivity, political neutrality amongst others and rendered efficient services to the people in the Western region (Omoyele, 2012).

Ogunrotifa, (2012) presented Chief Awolowo assessment of the defunct Western Regional public service in November 1959 as stated below that 'the public service in Southwest Nigeria is exceedingly efficient, absolutely incorruptible in its upper stratum, and utterly devoted and unstintingly committed in the discharge of its many onerous duties. For our public servants, government workers and labourers to bear, uncomplainingly and without breaking down, the heavy and multifarious burdens which we have (in the interest of the public) saddled them, is an epic of loyalty and devotion, of physical and mental endurance, and of a sense of mission. From the bottom of my heart I salute them all.'

Unfortunately, the position held by Chief Obafemi Awolowo in 1959 no longer holds sway today. The ethos of the present public services in Southwest Nigeria leaves much to be desired. Changes in government particularly at the state level often lead to the victimisation, frustration, wholesale transfer and sometimes outright dismissal of public servants. Although, the Post-independence public service in Nigeria inherited ethos and traditions of the colonial service among which were continuity, political neutrality, and anonymity, sadly, some of these traditions seem to be non-existent anymore. Today, relationship existing between political office holders and higher public servants is mostly characterised by and associated with passion, tension, undue interference, manipulation and conflict rather than cooperation. Tanner (2007) identified the centrality of political neutrality as an important component of the relationship between political functionaries 
and higher public servants. He argued that the convention of political neutrality in the management of public servants was an important aspect of politico-administrative relations.

In 1959, the Western Regional public service was described by Ogunrotifa (2012) as the best in the entire country. This feat was attained because of the existence of cooperative politics-administration relations in Southwestern Nigeria. The relationship between political functionaries and public servants in Southwestern Nigeria was conducive to achieving administrative competence and higher professional standards with the view to ensuring efficient service delivery for the wellbeing of the people of the region.

The afore-stated peculiar characteristics of political-administration interface manifest across all the regimes and regime types. The characteristics were more prominent during the fourth Republic with the cases of mass retrenchment in Governor Akande's administration, former President Obasanjo's down-sizing and right-sizing policies, irregular merging and demolition of some schools without recourse to administrative procedure, the mass sack of Igbo people from Lagos by the former Governor Fashola of Lagos State among others, exemplified few cases of political-administration interface in the fourth republic.

In recent times, relationship between public servants and political office holders has been strained and this has resulted in suspicion whereby parties see themselves as competitors rather than partners in progress. In some occasions, political office holders perceive public servants as lethargic, incompetent, uncooperative and corrupt. Public servants, on the other hand see political functionaries as parochial, greedy, self-seeking, self-centred, inexperienced, immature, highly wasteful and often unwilling to abide by the rule of law cum due process, which constitute the bedrock of bureaucracy.

Public service in Southwestern Nigeria has continued to witness recurring, persistent and ugly incidence of political-administrative relations arising from the interface. The crisis emanating from the interface in Southwestern Nigeria is discernible in public servants performing duties of political executives and generally conducting themselves as political functionaries as against the laid down ethos. Moreover, the crisis of interface has led to the jumping of official channels of communication often to subvert superiors before the political leadership, thereby creating feelings of alienation that may breeds discontent. Public servants in the Southwest geo-political zone sometimes publicly 
enunciate or comment on decided government policies; even openly canvassing partisan political views and registering as card carrying members of political parties in their states. All the above actions and more are in direct contravention of the existing regulations, accepted norms and ethics of the public service.

Lack of strict adherence to the ethos of neutrality, anonymity, impartiality, efficiency, accountability, discipline, hard work, integrity, professionalism etc. are capable of making public servants in Southwest Nigeria exhibit traits of partisanship, partiality and other primordial factors. Today, public servants are seen and heard. They openly canvass for votes and support the ruling political party in the state. If all these misconducts are not promptly and adequately checked they are likely to impact negatively on the performance of public servants. All these aforementioned could also have untold consequences on the proper functioning of the public service and impairs public service delivery in Southwestern Nigeria.

\section{DATA ANALYSIS, RESULTS AND DISCUSSION}

Four ministries which included: Ministries of Works and Transport, Education, Finance and Agriculture were randomly selected within the study area respectively. The reason for the choice of these ministries is strategic. These ministries can be described as important to this study because of the essential services they render. The population of study include middle level staff from grade levels 7-10 and management staff from grade levels 12 and above. The population involved workers in the administrative and executive cadres. The management staff includes permanent secretaries, directors and deputy directors. The reason why the study focused on these categories of workers is because they help to keep the machinery of administration functional and readily available for the political leadership of the various ministries and departments. The study has a sample of five hundred and thirty-five (535) respondents, which constitutes 50 percent of the total population figure of 1070. Purposive random sampling techniques were adopted to determine the target respondents.

The study used primary and secondary methods of data collection. Quantitative data were collected through personally administered questionnaire on various categories of public servants. While qualitative data were extracted through the conduct of personal interview. In order to complement the data from primary, some information were collected through secondary sources. The secondary materials were sourced from 
academic literature on the subject matter, the various publications of the selected ministries, internet materials, textbooks and relevant classified government publications.

Table 1: Cases of Political-administration interface in Southwest Nigeria

\begin{tabular}{|c|c|c|c|c|}
\hline Description & SA & A & D & SD \\
\hline $\begin{array}{l}\text { Politics and administration cannot be } \\
\text { separated in the delivery of public } \\
\text { services }\end{array}$ & $\begin{array}{c}97 \\
(33 \%)\end{array}$ & $\begin{array}{c}25 \\
(8.6 \%)\end{array}$ & $\begin{array}{c}130 \\
(44.5 \%)\end{array}$ & $\begin{array}{c}40 \\
(15.3 \%)\end{array}$ \\
\hline $\begin{array}{l}\text { Political appointees (e.g. Governors, } \\
\text { commissioners etc.) are superior to } \\
\text { career office holders in the public service } \\
\text { system }\end{array}$ & $\begin{array}{c}155 \\
(53.1 \%)\end{array}$ & $\begin{array}{c}91 \\
(31.2 \%)\end{array}$ & $\begin{array}{c}36 \\
(12.3 \%)\end{array}$ & $\begin{array}{c}10 \\
(3.4 \%)\end{array}$ \\
\hline $\begin{array}{l}\text { Political appointees and career office } \\
\text { holders are independent of each other } \\
\text { when discharging their duties/functions }\end{array}$ & $\begin{array}{c}29 \\
(9.9 \%)\end{array}$ & $\begin{array}{c}20 \\
(6.8 \%)\end{array}$ & $\begin{array}{c}200 \\
(68.5 \%)\end{array}$ & $\begin{array}{c}43 \\
(14.7 \%)\end{array}$ \\
\hline $\begin{array}{l}\text { The relationship between political } \\
\text { appointees and career office holders in } \\
\text { the ministries is cordial and harmonious. }\end{array}$ & $\begin{array}{c}209 \\
(71.6 \%)\end{array}$ & $\begin{array}{c}55 \\
(18.8 \%)\end{array}$ & $\begin{array}{c}11 \\
(3.8 \%)\end{array}$ & $\begin{array}{c}17 \\
(5.8 \%)\end{array}$ \\
\hline
\end{tabular}

Source: Field survey, 2015

Table 2: Factors Influencing the Interface of Public Servants and Political Functionaries

\begin{tabular}{|c|c|c|c|c|}
\hline Description & SA & A & D & SD \\
\hline $\begin{array}{l}\text { The cultural environment assists in } \\
\text { determining the nature of relationship } \\
\text { between the political appointees and } \\
\text { career office holders. }\end{array}$ & $\begin{array}{c}231 \\
(79.1 \%)\end{array}$ & $\begin{array}{c}35 \\
(11.9 \%)\end{array}$ & $\begin{array}{c}15 \\
(5.1 \%)\end{array}$ & $\begin{array}{c}11 \\
(3.8 \%)\end{array}$ \\
\hline $\begin{array}{l}\text { Poverty is a wage differential function that } \\
\text { contributes to the nature of the } \\
\text { relationship between political appointees } \\
\text { and the career office holders. }\end{array}$ & $\begin{array}{c}190 \\
(65.0 \%)\end{array}$ & $\begin{array}{c}49 \\
(16.7 \%)\end{array}$ & $\begin{array}{c}33 \\
(11.3 \%)\end{array}$ & $\begin{array}{c}20 \\
(6.8 \%)\end{array}$ \\
\hline $\begin{array}{l}\text { Politicisation in administrative matters; } \\
\text { with respect to appointment, promotion } \\
\text { and transfer are key determinants of the } \\
\text { nature of relationship existing between the } \\
\text { political appointees and career office } \\
\text { holders. }\end{array}$ & $\begin{array}{c}119 \\
(40.7 \%)\end{array}$ & $\begin{array}{c}120 \\
(41.1 \%)\end{array}$ & $\begin{array}{c}10 \\
(3.4 \%)\end{array}$ & $\begin{array}{c}43 \\
(14.7 \%)\end{array}$ \\
\hline Avarice; which is extreme greed for wealth, & 209 & 55 & 17 & 11 \\
\hline
\end{tabular}




\begin{tabular}{|l|c|c|c|c|}
\hline $\begin{array}{l}\text { material gain and undisciplined love of } \\
\text { money is another factor that is responsible } \\
\text { for the nature of the relationship between } \\
\text { the political appointees and the career } \\
\text { office holders }\end{array}$ & $(71.6 \%)$ & $(18.8 \%)$ & $(5.8 \%)$ & $(3.8 \%)$ \\
\hline $\begin{array}{l}\text { Differences in background and orientation } \\
\text { between political appointees and career } \\
\text { office holders affect the character and the } \\
\text { nature of relationship. }\end{array}$ & $(54.4 \%)$ & $(35.9 \%)$ & $(4.8 \%)$ & $(4.8 \%)$ \\
\hline
\end{tabular}

Source: Field survey, 2015

Table 3: Effect of the Interface on Public Service Ethos in Southwest Nigeria

\begin{tabular}{|c|c|c|c|c|}
\hline Description & SA & A & D & SD \\
\hline $\begin{array}{l}\text { The relationship often results into } \\
\text { partisanship of the civil system in the state. }\end{array}$ & $\begin{array}{c}195 \\
(66.7 \%)\end{array}$ & $\begin{array}{c}60 \\
(20.5 \%)\end{array}$ & $\begin{array}{c}30 \\
(10.3 \%)\end{array}$ & $\begin{array}{c}7 \\
(2.4 \%)\end{array}$ \\
\hline $\begin{array}{l}\text { The nature of the relationship between } \\
\text { political office holders and career public } \\
\text { servants discourage job security and } \\
\text { commitment to work. }\end{array}$ & $\begin{array}{c}135 \\
(46.2 \%)\end{array}$ & $\begin{array}{c}111 \\
(38.0 \%)\end{array}$ & $\begin{array}{c}36 \\
(11.6 \%)\end{array}$ & $\begin{array}{c}10 \\
(4.1 \%)\end{array}$ \\
\hline $\begin{array}{l}\text { The relationship induces / encourage } \\
\text { corruption and all other unethical behaviour }\end{array}$ & $\begin{array}{c}190 \\
(65.1 \%)\end{array}$ & $\begin{array}{c}70 \\
(23.9 \%)\end{array}$ & $\begin{array}{c}17 \\
(5.8 \%)\end{array}$ & $\begin{array}{c}20 \\
(6.8 \%)\end{array}$ \\
\hline $\begin{array}{l}\text { The relationship has increased the tendency } \\
\text { to promote politics over administration. }\end{array}$ & $\begin{array}{c}219 \\
(75.0 \%)\end{array}$ & $\begin{array}{c}55 \\
(18.8 \%)\end{array}$ & $\begin{array}{c}11 \\
(3.8 \%)\end{array}$ & $\begin{array}{c}7 \\
(2.4 \%)\end{array}$ \\
\hline
\end{tabular}

Source: Field survey, 2015

Table 4: A Cross Tabulation Covering $X^{2}$ Calculation and P-Value Used in Testing the Cases of Political-administration interface in Southwest Nigeria

\begin{tabular}{|c|c|c|c|}
\hline \multicolumn{4}{|c|}{ Chi-square tests } \\
\hline & Value & Df & Asymp. Sig. (2-sided) \\
\hline Pearson Chi-Square & $291.955^{a}$ & 195 & 0.05 \\
\hline Likelihood Ratio & 277.199 & 195 & 0.05 \\
\hline Linear-by-Linear Association & 3.855 & 1 & 0.05 \\
\hline Nof Valid Cases & 292 & & \\
\hline
\end{tabular}


Source: Authors' own calculation through SPSS version 16

Hypothesis One: Political-administration interface does not exist in Southwest Nigeria.

The table 4 above showed that the Pearson Chi-Square (291.955) is greater than p-value of (0.05), the Likelihood ratio of (277.199) is greater than p-value of $(0.05)$, Linear by Linear association of (3.855) is greater than the p-value of (0.05), hence the null hypothesis is rejected that says that political-administration interface does not exist in Southwest Nigerian and the alternative hypothesis is accepted, that politicaladministration interface exists in Southwest Nigeria.

Table 5: Factors Influencing the Interface of Public Servants and Political Office Holders in Southwest Nigeria

\begin{tabular}{|c|c|c|c|c|c|c|}
\hline \multicolumn{7}{|c|}{ T-test Analysis } \\
\hline & \multicolumn{6}{|c|}{ Test Value $=0$} \\
\hline & \multirow[t]{2}{*}{$\mathbf{T}$} & \multirow[t]{2}{*}{ d.f } & \multirow[t]{2}{*}{ Sig. (2-tailed) } & \multirow[t]{2}{*}{$\begin{array}{c}\text { Mean } \\
\text { Difference }\end{array}$} & \multicolumn{2}{|c|}{$\begin{array}{c}95 \% \text { Confidence Interval } \\
\text { of the Difference }\end{array}$} \\
\hline & & & & & Lower & Upper \\
\hline VAR0001 & 28.888 & 195 & .000 & 1.932 & 1.82 & 2.04 \\
\hline VAR0002 & 25.370 & 195 & .000 & 1.418 & 1.26 & 1.58 \\
\hline VAR0003 & 25.934 & 195 & .000 & 1.541 & 1.41 & 1.68 \\
\hline VAR0004 & 33.249 & 195 & .000 & 2.048 & 1.95 & 2.14 \\
\hline VAR0005 & 20.195 & 195 & .000 & 1.952 & 1.82 & 2.09 \\
\hline
\end{tabular}

Source: Authors' own calculation through SPSS version 16

Hypothesis two: There are no significant factors influencing the interface of public servants and political functionaries in Southwest Nigeria

From the table 5 presented above, five (5) variables were tested in respect to factors influencing the interface of public servants and political functionaries in Southwest Nigeria. The results showed variables tested as follows; Cultural environment assists in determining the nature of relationship between the political appointees and career office 
holders, $\left(t^{*}=28.888>0.05\right)$; poverty is a factor that contributes to the nature of the relationship between political appointees and the career office holders, $\left(t^{*}=25.370>0.05\right)$; political incursion into administration is a key factor to the nature of the relationship between the political appointees and career office holders $\left(t^{\star}=25.934>0.05\right)$; Avarice which is extreme greed for wealth, material gain and undisciplined love of money is another factor that is responsible for the nature of the relationship between the political appointees and the career office holders $\left(t^{\star}=33.249>0.05\right)$; Differences in background and orientation between political appointees and career office holders affect the character and the nature of relationship $\left(t^{*}=20.195>0.05\right)$.

In conclusion, the t-test statistical tools used to examine the factors responsible for the nature of relationship between political appointees and career office holders "(i.e. Variables (0001-0005)" tested and mentioned above are strongly responsible for the said relationship between the two office holders. The calculated $t$ value significant at $0.05 \%$ level, i.e. there is a $95 \%$ chance of the means significantly similar. By convention, similarities between the tested means at the 95\% level are "highly significant". Therefore, all the variables administered and tested for the study confirmed strong influence between both parties.

Table 6: Model summary of the simple Regression for Public service ethos

\begin{tabular}{|rcccc|}
\hline Model & $\mathbf{R}$ & R Square & $\begin{array}{c}\text { Adjusted } \mathbf{R} \\
\text { Square }\end{array}$ & $\begin{array}{c}\text { Standard error of the } \\
\text { estimate }\end{array}$ \\
\hline $\mathbf{1}$ & $\mathbf{. 8 1 2}$ & $\mathbf{. 6 9}$ & $\mathbf{. 5 7}$ & $\mathbf{1 5 7 . 4 3 3 6}$ \\
\hline
\end{tabular}

Table 7: Summary of Analysis of Variance for public service ethos

\begin{tabular}{|ccccccc|} 
Model & Variations & $\begin{array}{c}\text { Sum of } \\
\text { Square }\end{array}$ & d.f & $\begin{array}{c}\text { Mean } \\
\text { square }\end{array}$ & F & Sig, \\
\hline 1 & Regression & 762 & 1 & 762 & 26.34 & 0.05 \\
\hline & Residual & 1946 & 56 & 38 & & \\
\hline & Total & 2708 & 57 & & & \\
\hline
\end{tabular}

Source: Authors' own calculation through SPSS version 16 
Hypothesis 3: The interface has no significant influence on public service ethos in southwest Nigeria.

To test the third hypothesis, simple regression analysis was used to run the independent variable against dependent variable used in determining dependent variable. Table 6 above indicates the model summary of the simple regression equation that predicted public service ethos. The explanation of the values presented is given in the table below.

The model summary table provides useful information about regression analysis. First,

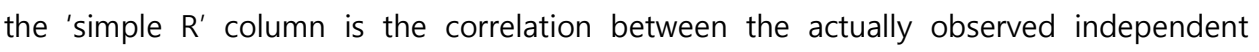
variable and the predicted dependent variable (i.e. predicted by the regression equation). ' $R$ square' is the square of $R$ and is also known as the 'coefficient of determination.' It states the proportion (percentage) of the (sample) variable in the dependent variable that can be attributed to the independent variable(s). In this study $69 \%$ of the variations in public service ethos among political office holders and career public servants could be accounted for by the cordial relationship between them. The adjusted $R$ square refers to the best estimate of $R$ square for the population from which the sample was drawn. Finally, the 'standard error of estimate' indicates that, on average, observed entrepreneurial productivity deviate from the predicted regression line by a score of 177.4436, the hypothesis which stated that "The interface has no significant influence on public service ethos in southwest Nigeria was rejected at $R=.819, R 2=.69, F$ (1.48) $=.26 .34 ; \rho<.05$. This implies that there is a significant influence of the interface on public service ethos in southwest Nigeria.

\section{Findings}

The findings of the study showed amongst others that politics-administrative interface existed in the Southwest geo-political zone of Nigeria. This is as a result of difficulty in separating politics from administration. The study observed also some form of synergy between political office holders and public servants. This finding is supported by Pepper (2013) who identified a synergy between political functionaries and career public servants in Southwest Nigeria. He claimed that political-administration interface in the Southwest is necessary for proper administration of the geo-political zone. 
Moreover, there exists a great deal of ascendancy of politics over administration. In Southwest Nigeria there is a strong influence of politics over administration. This has further enhanced the interface and made public servants politically active rather than being politically neutral. This is confirmed by Adamolekun (1993) who contended that the dominance of the political officials over the instruments of administration existed in Nigeria, at least, in theory

The study equally revealed that there were several factors influencing the interface of public servants and political office holders in the selected states of the region. Factors like differences in educational background, competing interests of both public servants and political office holders influence, others are factors bordering on accountability, due process, remuneration, procurement, contract awards, role ambiguity, appointment of top public servants, recruitment into the public service, promotion, transfers inferiority complex on the part of public servants etc. influenced the interface of public servants and political office holders.

The study found that there was a great influence of the interface on public service ethos in the selected states in the Southwest Nigeria. It was discovered that the interface negatively affected transparency and the loyalty of public servants to their political bosses in Southwest Nigeria. It was revealed that the interface made public servants in the selected states to sometimes over-align themselves to the ruling political parties in the states; a situation that militates against political neutrality and affects efficient service delivery. Political neutrality helps to engender confidence in the institution. In the Southwest, it is a common practice to see public servants participating in political rallies, campaigns and other political activities in order to secure their jobs. In most of the ministries, party stickers of the ruling political parties were pasted on the doors of both junior and senior public servants. A public servant that is not politically loyal is sometimes arbitrarily transferred or generally victimised.

It was observed that efforts by professional bodies, states' public service commissions, disciplinary committees, government intervention among others mitigated the harmful effect of the erosion of public service in the Southwest.

\section{Concluding Remarks}

This study essentially examined political-administration interface and the sustenance of public service ethos in Southwest Nigeria. The study showed the significance of 
harmonious relationship between political office holders and career public servants in the area of study. The study concluded that despite the commendable efforts made by Public Service Commissions in the selected states, political-administration interface failed to enhance compliance with ethical practices of the public service in Southwest Nigeria.

\section{Recommendations}

In the light of the above findings, this study made the following recommendations:

First, there is the need to strengthen the politics-administration relations in Southwest Nigeria. The interface between public servants and political office holders should be harmonious and be able to enhance productivity, performance and efficiency in the public service. The interface should resort to mutual trust and respect rather than suspicion. The interface should be positively engaged. There is the need to safeguard political neutrality and impartiality of the public services in the three selected states in Southwest Nigeria.

Secondly, the various factors inhibiting cooperative interface between political functionaries and public servants in the Southwest geo-political zone of Nigeria must be urgently addressed. This can be done in several ways. First, politically motivated sanctions of career public servants, corrupt tendencies, inordinate political ambition, political patronage, political consideration in appointment of permanent secretaries, frequent transfers, improper understanding of each other's respective roles and other primordial factors that likely to affect the relationship between parties should be addressed.

Moreover, public servants should act in such a way that will make them earn the respect and confidence of political office holders. Public servants must desist from participating in partisan politics. They should always give their honest, neutral, impartial and comprehensive advice to the political functionaries. They should always avoid commenting on clearly political issues or topics mooted by political parties in the Southwest zone of Nigeria. Public servants in the Southwest geo-political zone of Nigeria should always ensure that they exhibit professional, neutral and impartial relationship with political functionaries. This will ensure that the public service provides strong support for the good government of Southwest Nigeria in the long run.

Finally, government in the Southwest geo-political zone of Nigeria should organise retreats on a regular basis for both political functionaries and career public servants, 
including: Commissioners, Special Advisers to Governors, Personal Assistants, Permanent Secretaries and the entire members of the State Executive on the need to uphold the ethics and principles of the service as well as adhere to their respective codes of conduct for public sector officers.

\section{List of References}

- Abiona, F.O. \& Oladoyin, A.M. 2008. From policy to result-based implementation. Anniversary Lecture. Nigerian Public Service Week in Osun State. Osogbo: Atman Publishers.

- Adamolekun, L. 2013. The politics-administration nexus: Two doctrines and four recommendations. In Adamolekun, L. (ed). Higher Civil Servants and their Political Masters. Ibadan: Caligate Publishing Company Limited.

- Adamolekun, L. 1983. Politics and administration in Nigeria. Ibadan: Spectrum Books Limited.

- Adegoke, L. 2013. Higher public servants and their political masters: Four key causes of conflicts. In Adamolekun, L. (ed) Higher Public servants and their Political Masters. Ibadan: Caligate Publishing Company, Limited.

- Akinola, F. 2012. The incessant sack of career public servants in The Daily Trust, May $31^{\text {st. }}$ 2012.

- Almond, G. 2006. Comparative Politics Today: A World View. New Delhi: Dorling Kinderley

- Agba, M.S. Ochimana, G.E. \& Abubakar, Y.I. 2013. Public service ethics and fight against corruption in Nigeria. A critical analysis. International Journal of Public Administration and Management Research. 2(1): 112-118.

- Amaechi, C. M. 2010. Democratization in Nigeria: Nation building versus state buildings International Journal of Development and Management Review. (INJODEMA). 5 (1)

- $\quad$ Appleby, R. 1984. Modern Business Administration. London: Pitman Publishing Limited.

- Avritzer, L. 2002. Democracy and the public service in Latin America. Princeton: Princeton University Press. 
- Barnes, T.D. \& Burchard, S.M. 2013. Engendering politics: The impact of descriptive representation on women's political engagement in Sub-Saharan African Engendering Politics: the impact of Descriptive Representation on Women's Political Engagement in Sub-Saharan Africa. Journal of Comparative Political Studies. 46(7): 767-790.

- Brans, M. 2005. Comparative public administration: From general theory to general frameworks. Peters, B.G \& Pierre, J. (eds). Handbook of Public Administration. London: Sage Publications

- Carboni, N. 2010. Changing relationship between politicians and bureaucrats in contemporary democracies: An empirical analysis of Italian experience. International Public Management Review. 11(1): 22-43.

- Daly, M. 2012. Accountability among Senior Public servants. Dublin: Institute of Public Administration.

- Dasandi, N. 2014. The Politics-Bureaucracy Interface Impact on Development Reform. Birmingham: Developmental Programme Leadership Publishers.

- Demir, T. 2008. The Politics-Administration Dichotomy: An Empirical search for correspondence between theory and practice. Public Administration Review.3 (6): 81-102.

- Fatile, J.O 2007. Approaches to the Study of Public Administration. In Olojede, I. \& Fajonyomi, B. (eds.) Essentials of Public Administration. Lagos: Department of Public Administration, Lagos State University.

- Iheme, E.I. 2003. The Prohibition of Public servants from Politics in Nigeria. The International Journal of Not-For-Profit-Law. 6(1), 1-7

- Ipinlaye, O. 2001. The Nigerian Public service: An Insider's Views. In Omotoso, S.I (ed). Contemporary Issues in Public Administration.

- Kwaghga, B. 2014. Challenges of Ethics and Accountability in Nigerian Civil Service. Journal of Poverty, Investment and Development. 3(1): 1-5.

- Lasswell, H. 1934. Politics: Who Gets What, When and How. The American Political Science Review in William Searl Carpenter. 30 (6), 1174-1176

- Laximikanth, M. 2011. Public Administration. New Delhi: Tat McGraw

- Maduabum, C. 2002. Transition and the Nigerian Public service in Onuoha B. \& Fadakinte M.M. (eds). Transition Politics in Nigeria. 1970-1999. Lagos: Malthouse Press Limited. 
- Nchuchuwe, F.F. 2007. Historical Development of Public Administration. Olojede, I. \& Fajonyomi, B. (eds.) Essentials of Public Administration. Lagos: Department of Public Administration, Lagos State University.

- Ndudula, M.R. 2013. Analysis of the Politics-Administrative Interface and its Impact on Delivery of Municipal Services. Forte-hare. University of Fort Hare Press.

- Needham, C. 2007. A Declining Public Service Ethos? In Dibben, P. et al (eds.) Modernizing Work in the Public Services. London: Palgrave Macmillan.

- Nicholas, H. 2003. Public Administration and Public Affairs New Delhi: Prentice-Hall of India.

- Nti, J. 1978. Public service in Ghana: Its Appraisal and Prospects. Accra: Ghana Universities Press.

- Nwasike, J. 2013. Reinventing Trust: The Political Administration Interface in Caribbean Small States. Commonwealth Governance. London: Commonwealth Handbook.

- Oladoyin, A.M. 2012. Effects of Politics on Local Government Administration in Nigeria. In Aransi 1.0 (ed). (2012). Local Government in Nigeria: Essays for Professor Oladimeji Aborisade. California: Warren Publishing, Inc.

- Olaleye A. O. 2004. The public service and Development in Nigeria in Ola R.F., \& Agasu A.A. (eds). Development Agenda of the Nigerian State. Ibadan: Flag (Nigeria) publishers.

- Olaopa, T. 2008. Theory and Practice of Public Administration and Public Service Reforms in Nigeria. Ibadan: Spectrum books Ltd.

- Olowu, D. 1999. Centralization, Self-Governance and Development in Nigeria. In Wunsch, J. \& Olowu, D. (eds). Failure of the Centralized State: Institutions and Governance in Africa. Boulder: West View Press.

- Okotoni, O, \& Eroro, J. 2005. Manpower Training and Development in the Nigerian Public Service, $2^{\text {nd }}$ of August, 2005. Department of Public Administration, Obafemi Awolowo University, lle Ife, Nigeria Website: http://unpan1.un.org/intradoc/groups/public/documents http://rss.indiainfo.com., (April,21st).

- Omoyele, E.O. 2012. The Public service in Nigeria: Evolution and Challenges. Lagos: CSS Book Publishers.

- Pepper, C. I. 2013. The Relationship between Higher Public servants and their Political Masters. In Adamolekun. L. (ed). Higher Public servants and their Political Masters. Ibadan: Caligate Publishing Company Limited. 
- Rohr, A. 2003. A Study of Politics and Administration: An Introduction of Frank Goodnow Work. New York: Amazon Publishers.

- Qasim, S., Mehwish, S., \& Akram, N. 2011. 'Degree of Influence of Training and Development On Employees Behaviour (March $3^{\text {rd }}-6^{\text {th }}, \quad$ 2011) http://www.researchmanuscript.com.on

- Wiarda, H.J. 2002. New directions in comparative politics. Boulder: West view Press

AUTHOR'S CONTACT:

\section{AFEGBUA, Salami Issa}

Dept. of Public Administration Lagos State University

Ojo, Nigeria

Email: issa99_afegbua@yahoo.com 